\title{
The Principle of Neighbourliness as a Religious Issue for Societal Development
}

\author{
Ogirima Nuhu \\ Department of Islamic Studies, \\ Federal College of Education, Okene, Kogi State,Nigeria
}

\section{Doi:10.5901/mjss.2013.v4n8p9}

\begin{abstract}
Religion has been viewed ambivalently by various people, both adherents and non-adherents. This is against the backdrop of resurgence in religion-based violence across the world. Against this premise, the paper sought to characterize the major crises, particularly in Nigeria, as basis for the affirmation of the assumed premise, which is that development is hinged on societal integration which is realistic only on the principle of good neighbourliness, in the postulations of the Islamic faith. The paper also clearly unravels bigotry and not the faith itself as the major causal factor of religious crises hence the recommendation of early childhood religious education, with emphasis on the sociology and culturally integrative aspects of the teachings of the various religions, among others, for societal development.
\end{abstract}

Keywords: Religion, Good Neighborliness, Societal Integration.

\section{Introduction}

Religion has perhaps never been so criticized, condemned and indeed relegated as has been the case since the high profile unimaginable bombings began in September, 2011. These events are as unprecedented as the provocation of hostilities they engendered, especially against the faithful of the Islamic faith, which the perpetuators of the bombings claim. People of the faith have more than been alienated not only in US and Europe, which have been in forefront of the war against such faith-acclaimed individuals and groups responsible for the violence, but also in developing countries: from East to North and, indeed, West Africa in particular.

The resurgent faith-based crises have sought to obscure the relevance of religion in the life of man in contemporary discourse. To non-believers, there is probably no such thing as religion given the perceived negativity arising from the virulent violence being perpetuated by those who profess it. Whereas the question of religion, to adherents in particular, is unquestioningly an indispensible tool for societal peace and integration, however culturally divergent and or crises-ridden, as the case may be, without which development would be a mirage.

While providing the bases for the resurgence of religious crises would be quite repetitive, it is, however, necessary to note that different manifestations of the factor of bigotry, as the basic cause, has resonated through the years (Ujjah, 1994; Sampson, 2012; WCC and RABIIT, 2012). On the other hand, the arrest of perpetrators who have variously consistently maintained their avowed armed conflict with the supposed enemies of their faith, Islam, reveal strong resentment to values considered quite antithetical to their shared beliefs. The overt expression and violent manifestation of hate, no doubt, has more often created not only sociological but cultural challenges for other Muslim faithful across the globe, most of whom, paradoxically/ironically, either do not share such views on armed conflict, albeit quietly, or are outright in opposition. 
Since situations vary according to the different countries, the imperative for an effective and sustainable universal solution was the drive of this researcher hence the further examination of the principle of neighbourliness as practical solution to the menace. This has also been considered quite expedient since, on careful examination, there has been some measure of unanimity of opinion amongst adherents of the orthodox divine religions; Judaism, Christianity and Islam, on the issue in question.

\section{Characterization of the Religious Crises}

Religions, as evident in their source documents, seek to promote societal integration necessary for the realization of the desired overall development. While it is undeniable that certain provisions tending towards particularism and emphasis on superiority over other similar faiths exist, it is pertinent to note that gross manifestation of bigotry in various forms, traceable to adherents of religions, have been largely responsible for the inter and intra-religious crises. This submission diametrically contrasts with those of Danjibo and Onuoha, in Sampson (2012), who believe that the Maitatsine disturbances and the current Boko Haram sectarian violence are both products of dogmatic adherence to Shari'ah Jurisprudence, which inspires Islamic Jihad and the obliteration of Western civilization'. This assumption has no basis as it is quite evident that the Shari'ah itself encourages universal scholarship and the search for knowledge without equivocation. However distant the source of its acquisition, knowledge, irrespective of its form, is enjoined but its utilization is not without conditions; this is the import of the prophetic traditions which encourages the search for knowledge, even if one has to travel to China, and constant exhortation of the Qur'an for believers to beware of the Devil in all affairs. The Prophet Muhammad could not have been said to be oblivious of the cultural differences or differences in civilizations when he laid emphasis using China, a distant country with its form of civilization at the time.

Also the unsubstantiated characterization of the Maitetsine and the contemporary Boko Haram by means of the concept of Jihad, as discussed under 'How these factors activate religious violence in Nigeria' by the authors cannot be said to be based on facts. Jihad, in the context of war, is basically a defensive last resort. This has been well articulated:

In addition to the foregoing, findings from research and interviews of volunteers especially from communities that have witnessed faith-based violence reveal substantial evidence to aver that most of the religious crises assumed such descriptions from the perspective of people extraneous to the supposed religions. This stems from the fact that the perceptions of men are more often based on various influences. In this regard, the submission of Walter (1972) comes to mind. He submitted that

Men sometimes view religion from outside looking in, sometimes from inside looking out and sometimes from inside looking around. Where they stand has a bearing on what they see and what they see is instrumental to what they do: what they do influence what they discover and how they stand ( $p .2)$

Furthermore, although perpetuators may have borne semblances of followership of the faiths they claim, evidences abound that they were not, as they have been way out of the fundamentals of their acclaimed religious belief by virtue of what they indulge in. Investigations by this researcher reveal that in some instances, international conspiracy has also been identified as responsible. All this are quite evident in the following findings on the major religious crises that Nigeria has witnessed in the past three decades:

\subsection{0: The Maitatsine Riot in Kano}

The precursor to this crisis was the reported kidnapping, raping and unexplained murder in the Yan Awaki area of Kano. Investigations reveal that the local residents accused one Muhammad Marwa, nicknamed 'Maitetse', and his followers. Although they profess Islam as a religion, true faithful clearly saw the hypocrisy and unlslamic tendencies given the fact that his activities run contrary to the religious injunctions. Indeed, the 
religion, unequivocally, forbids such atrocities and acts of criminality (Council of Ulama, in Ali, 1979, rendering of Qur'an 17:31 - 37). Consequently, an inra-religious crisis, popular revolt against him, broke out on $18^{\text {th }}$ December, 1980 and continued till $29^{\text {th }}$ December of the same year, leaving in its wake severe destruction of lives and property. The report of the Justice Aniagolu Panel, which concluded its assignment on $14^{\text {th }}$ April, 1981 having been constituted on $5^{\text {th }}$ April, 1981, revealed that the Maitetsine uprising was executed by non-Nigerians whose composition was '162 nationals of Niger Republic, 16 Chadians, 4 Camerounians, 2 Malians and I Burkinabe' (Ujjah, 1984: 19 ff).

\subsection{2 and 1984: Bulumkutu and Jimeta in Bornu and Adamawa States Respectively}

These two crises share much in common. As a matter of fact, findings establish strong relations of the rioters in these areas with their counterparts of 1980 in Kano. The link leaves sufficient ground to submit that the perpetuators may have been those who escaped the military onslaught against the Maitetsine group in Kano. Evidence abound, as published by Times International (1985) that:

Those who took part in Kano riot had an ' $X$ ' and dots inside a circle tattooed on each fanatics back; those who took part in Bulumkutu riot had an ' $X$ ' only inside the circle and those who took part in the Jimeta riot had one ' $X$ ' with no circle or dots (p. 9)

It could, therefore, be contended that the 30th October, 1982 and February, 1984 riots in Bulumkutu, Bornu state and Jimeta, Adamawa state respectively were the machinations of cults.

\subsection{7: Kafanchan, Kaduna State}

The Kafanchan inter-religious riot of 1987 may have been religious, given its origin from degeneration of a seemingly subtle dispute between a Christian and a Muslim in the College of Education in the area, according to the Justice Karibi-Whyte Tribunal, Police investigation unraveled the politico-tribal dimension of the reprisal accompanying it in the neighbouring communities. The Nigerian Newswatch (1987) reports that:

While the fracas in Kafanchan may have been religious in origin, the wanton destruction of lives and property in Kaduna, Katsina and Zaria were carefully planned and masterminded by evil men with sinister motives who saw the incident in Kafanchan as an opportunity to subvert the Federal Military Government and the Nigerian nation (p. 4)

\subsection{Year 2000: Kaduna, Kaduna state}

The Kaduna violent inter-religious crisis of the year 2000 sparked from the agitation against a supposed introduction of certain Shariah Legal Codes into the existing laws. However, reasons other than religion has been adduced for the bloody clash: in fact, the president at the time, Olusegun Obasanjo reportedly cautioned the Council of State against becoming 'tools in the hands of mischief makers who are out to rock the boat' (The Guardian, February, 24, 2000: 3); the report also had the president of the Christian Association of Nigeria at the time, Dr. Sunday Mbang, blaming 'anti-democratic forces using religion as guise'.

\subsection{The 'Boko Haram' Insurgency}

The 'Boko Haram', an epithet for the group which calls itself Jama'tu Ahlus-Sunnah Lid-Da'wati Wal-Jihad (People of the Tradition (Organized) for Propagation and Holy War (literally translated)) was formed in 2002 (Johnson in CFR, 2011). The organization became noted for its virulent violence and notorious in a range of atrocities, including bombings of public institutions among which was the UN Office in Abuja, Nigeria, in 
August, 2011 and kidnapping of women and children, some of whom were released in June 2013 after a military onslaught, from 2009. Details of the activities of the BH insurgency would be spared since the sect is not exclusively in the purview of this discussion.

However, it is expedient to state that, through the interview of a sample of the populace, people from some parts of Yobe state in particular, some startling revelations were made. These revelations tend to portray the group as apparently involved in some form of syncretism, which belies their avowed claim of orthodoxy. This is not however, suggestive of the non-acknowledgement of the context of emergence of the sect which is rooted in gross disenchantment with governance and the overall influence of the West. Nevertheless, with the execution of its founder and spiritual leader in 2009 , one could contend that $\mathrm{BH}$ managers became overzealous, fanatical, intolerant and extremely unorthodox, straying further from the ideals of Islam, which they had held so dear and for which they were endeared to societies - the immediate communities in Maiduguri area and people from across the northern states.

Compelling evidence to the effect that they practice syncretism can be found in the disclosure that they usually administer some rites alien to Islam to new converts. Accounts from oral interview have been corroborative on the gift of 'date' and 'Miswak' (chewing stick) for use by new converts to the sect. This is an alien practice/rite in Islam, which shall be discussed hereunder

\section{The Implications of the Principle of Neighbourliness on the Characterization of the Religious Crises}

The thrust of this paper derives from the conception of neighbourliness as a religious issue which, if properly harnessed, could impact positively in managing religious crises for the realization of peace and an atmosphere of orderliness, which is prerequisite for the attainment of societal development. A careful assessment of the preceding discussions would reveal that the interplay of neighbourliness can effectively contribute towards the eradication of violence, indeed atrocities, by religiously acclaimed individuals or groups.

In other words, a vigilant community maintaining the principles of good neighbourliness as postulated would not only effectively check religious deviants and help nip their plots in the bud, it would ensure a cohesive and firmly integrated community, united in the cause of humanity in general. The principle of neighbourliness presupposes that the good of all should be the common concern; everyone is his brother's keeper. This can be deduced from the several Prophetic traditions on the subject of social relations anchored on neighbourliness. For instance, Bukhari and Muslim in Fazlie (1993) narrated that the Prophet said:

I swear by Allah, he is not a Mu'min (believer). I swear by Allah, he is not a Mu'min. I swear by Allah, he is not a Mu'min. (on being asked, who was he, the Messenger of Allah \{SAW\} replied) The one from whose injurious conduct his neighbor is not safe. (p. 91)

The radial diagram below denotes the concept of neighborliness:

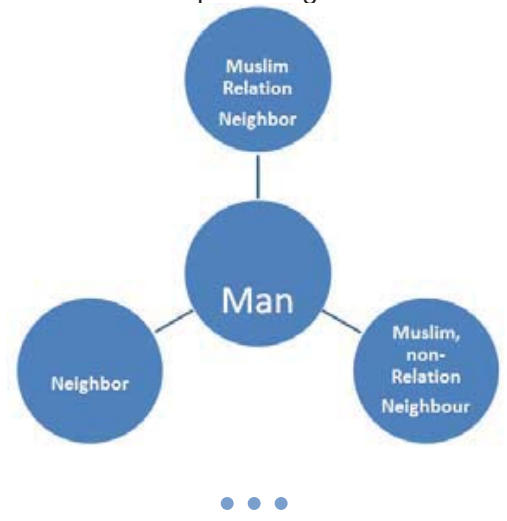


From the radial diagram, one can deduce that man is constantly surrounded by three sets of neighbours: people with whom he is related, by blood, and who may be his fellow in religion; or a relation not with whom he is not in the same religion; and a non-relation and non-religious fellow, just a neighbor. In all of these cases, the Islamic concept requires that he relates in a manner that promotes love, care and concern. In this regard, the tradition on the exhortation of Angel Jibril [Gabriel] comes to mind; the Prophet is reported telling his companions on the need for very strong care for the neighbor when disclosed that 'Jibril kept on recommending the neighbor to me so much that I thought he would make him an heir' (Bukhari and Muslim in Fazlie (1993: 91). Fazlie also reported the narration of the duo to the effect that the Prophet said that he who believes in Allah and the Last Day should not give trouble to his neighbor. In fact, the import of the Prophetic traditions in the foregoing is that good neighbourliness is considered as right.

$\checkmark$ The neighbor who is a relation and a Muslim;

$\checkmark$ The neighbor who is a relation but not a Muslim; and

$\checkmark$ The neighbor who is neither a relation nor a Muslim

These strata of the neighbourhood have certain implications; Islam confers the fundamental rights of good treatment, kindness and courtesy in speech and conduct to them, all categories, as listed; the first has three rights as stated i.e. good treatment threefold as a neighbor, relation and Muslim. The second has two rights, the right to good treatment as a neighbor and a relation irrespective of his religion. The third has an inalienable right to good treatment, however his creed or faith, as a neighbor, even though he may not be a kith and kin of one.

Where good neighborliness is held supreme, residents, however their religious inclination, would be expected to expose the evident manifestations of antithetical values such as the symbols identified with various groups of the most virulent sects in Nigeria history; the ' $X$ ' marks and the circles, the circles alone as identity marks and the ' $X$ ' without circles tattooed to the elbow or arm, as the case may be, of adherents. As a matter of fact, Islam is opposed to the practice of inscriptions onto the body as tattoo (Qaradawi, 1960: 88). The traditions of the Prophet invalidate this, and are in furtherance of the Qur'anic reference to avoid the footsteps of 'Ash-Shaitaan' (the Devil) through the avoidance of bodily transformations (Al-Qur'an, 4: 119). Besides, the religion sought to instill the spirit of selflessness in adherents in such matters which possibility/risk of self-pride and self-aggrandizement cannot be foreclosed. One given to self-praise is said to be indulging in Ar-Riya' (Self-praise, conceit, and doing things not for God but for others to appreciate, which the Prophet call a minor association with Almighty God and this, he said, erodes the reward of good deeds as water extinguishes fire).

The evident chauvinism and intolerance, cannot be doubted from the activities of the sects has no place in the religion (Qardawi, 1960: 247). The consequence could be found in the outbreak of violence, as have been witnessed over the years. Juxtaposed with the various manifestations of the violent sects pervading contemporary societies, a clear demarcation would become quite obvious and thus they could by some measure of convenience be termed deviants of Islam as a religion. Again, the effective means to check this lies in the vigilance of the community.

Furthermore, the evident use of unorthodox methods of conversion into the professed religions is great concern. The world's divine monotheistic religions, Christianity and Islam, share similar proselytization drive; i.e. as world acclaimed religions they require conveyance beyond the shores of the immediate place of revelation. Thus, the spread of Islam to climes other than the Arabian Peninsula is not without consequences. A clear example is obvious in the case where traditional cultural influences have dominated people prior to the introduction of Islam. Africa is one of such places. The intermingling of the African traditional religion with Islam created some form of worship quite antithetical to the issues of individual and public health concerns, including but not limited to spiritual well-being and up-bringing of all in manners envisioned by the religion of Islam. This neo-epithelial phenomenon, syncretism, has found acceptance in some African communities. It is quite unorthodox, as upholders of the tradition (Ahlus-Sunnah) have averred (Qardawi, 1960: 243). It is considered 'Shirk' (association with Almighty God, which is one of the worst sins). There is an attraction to 
evil through the utilization of other than religious provisions in terms of welfare needs of individual Muslims e.g. on issues of health and spiritual well-being especially. A clear illustration of the practice of syncretism can be seen amongst deviant groups/sects notably violent in the recent history of Islam, particularly in Nigeria. It is noted that the entry-point needs of identified deviant groups portray syncretism. Oral interviews of people across the Boko Haram ravaged areas, who had had contact with some adherents, reveal that at the entry point into the sect, a date-palm and 'aswak' (chewing stick) is distributed to new adherent of the sect's ideology. This is sequel to a birth followed by a prayer in congregation with the group. Critically examined, although the use of 'aswak' (chewing stick is encourage before every prayer, just as eating dates is considered good, the practice of giving particular one to a new convert by the leadership of the sect is alien to Islam: the Sunnah - Prophetic tradition for a new convert to Islam is to pronounce the 'KalimatusShahaadah' (statement of testimony, which reads: 'I testify that there is no deity worthy of worship except Allah and that Muhammad is His servant and Messenger'). Indeed, the established entry initiation rite does confirm the syncretic inclination of the group. Also the Maitatsine group had concoctions washed for new adherents. One could therefore aver that such practice is heretical, as this does not portray any semblance of the entry rite of the religion of Islam.

Thus, the utilization of means other than the prescribed channels of proselytization by such people to actualize their deeply driven mission cannot be said to have been spurred by other than self actualization hence the creation of niche which is suggestive of some crises of a sort. One could, therefore, say that is a manifestation of bigotry and an evidence of identity crisis. In the ultimate, it is the neighbours that could identify these traits, as they relate more often in their various communities, and report them for checks and appropriate action. This is encouraged by the Qur'an itself when it declares: "And fear the tumult/upheavals which affecteth not in particular (only) those of you who do wrong: and know that Allah is strict in punishment" (Qur'an, 8: 25).

The provision of atmosphere of peace and orderliness in the society is considered of paramount necessity. This is derivable from the family and its sustenance also rests with it, as a microcosm of the society. The cohesiveness which ensures the firmness of the integrative process of the society revolves around good neighborliness and a responsible leadership, or government, as the case may be. Contextually, a neighbor is not only he who resides next door it denotes the person with whom one shares a certain space or environment, temporarily otherwise; e.g. as in the case of people traveling in the same means of transport, people in same hostel or even hotel, and similar other places.

The prophetic traditions on socio-cultural aspects of Islam, as discussed, reveal a great deal of provision requiring strong commitment of believers towards peace, in all ramifications, and welfare of these classes of neighbours irrespective of the context.

\section{Conclusion and Recommendations}

The painstaking effort of this researcher towards ensuring credibility, through the employment of interviews and search for the reports on incidents of faith-based crises, in the quest for practical solution to the resurgent religious conflict does not suggest that all requisite postulations have been confirmed. This stems from the fact that people expected to provide insight into the inner working of known sects do not readily own up to their membership. This may not be unconnected to the consequence of such disclosures especially in the stigmatization by communities and or fear of possible prosecution by government. In most cases, At best, residents of the conflict-prone areas, some of whom this researcher did interviewed, offered some form of information which form the basis of the conclusions. Nevertheless, it remains a challenge for prospective researchers in this critical area of national development to explore ways of access to principal actors for firsthand information without which conjecture rather than the real motives may continue to dominate research works. 
It would be expedient to highlight this researcher's discovery of the easy susceptibility of adherents of religion to manipulation by extraneous forces (forces outside their professed faiths). This is indicative of either an improper grasp of the religious principles and doctrines or deliberate attempts to unleash terror by perpetuators of religious hate, crisis and violent conflicts.

Given the argument of this paper, the society would need to evolve policies that would ensure that the religious provisions on the sociology of human relations as pivot for peaceful coexistence as well as societal integration are instilled in the individual. For the realization of this, carefully outlined schools' curricula, with emphasis on those sociological aspects, would need to be drawn. Learners should be required to take such religious courses/lessons willy-nilly, as in the case of the compulsory subjects at the basic education levels (Primary and Junior Secondary schools levels).

Also, good public/human relations building, especially peaceful coexistence cannot be firmly integrated in exclusion of the microcosm of the society, the home. The values of family life should be enlivened through the appropriate channels which include, but not limited to, utilization of traditional institutions to inculcate communal value system, national orientation campaigns and, of course, relevant schools subjects.

In addition to the foregoing measures, the capacity of government security agents would need to be built and updated through constant but periodic training in intelligence gathering from the neighborhood so that rather than being reactionary in crises situations they could nip them in the bud.

\section{References}

Al-Qaradawi, Y (1960) (Translation by El-Helbawy K. et al, undated). The Lawful and the Prohibited in Islam (23 ${ }^{\text {rd }}$ ed.) Cairo, Egypt (Publisher not indicated)

Council of Ulama (1980) The Holy Qur'an, English Translation of the Meanings and Commentary (Revised Version of Ali, Y. (1970) Translation of the Qur'an)). Madinah: King Fahd Holy Qur'an Printing Complex.

Fazlie, MBJ (1993): Radiance: Sayings of the Prophet. Abul Qasim Publishing House, Jeddah.

Johnson, T. (2011). Boko Haram. US Council on Foreign Relations. Retrieved June, 2013, from http://www.cfr.org/world/boko-haram

Sampson, IT. (2012). Religious Violence in Nigeria: Causal Diagnoses and Strategic Recommendations to the State and Religious Communities. Retrieved May, 2013, from http://www.ajol.info/index.php/ajer/article

The Guardian, February, 24, 2000

Times International (1985) Vol. 6, no. 23, Pp. 13 - 19.

Ujjah (1984). Religious Bigotry in Nigeria. Times International, Vol. 5, no. 25.

Walter, C. (1972). Ways of Understanding Religion. New York: Macmillan.

World Council of Churches (WCC) and Royal Jordanian Aal Al-Bait Institute of Islamic Thought (RABIIT) (2012). Report on the Inter-Religious Tensions and Crisis in Nigeria. 
